\title{
Altering the Material Conditions of Access to the Humanities
}

\author{
John Willinsky
}

Mankind thus inevitably sets itself only such tasks as it is able to solve, since closer examination will always show that the problem itself arises only when the material conditions for its solution are already present or at least in the course of formation.

Karl Marx, Contribution to the Critique of Political Economy (1859)

This chapter enters this book through a side door, parenthetically left ajar by Derrida in his contribution to this collection - "(Although I must leave this aside...)" - as if space and time did not permit him to open the issue more than a crack, even as he names it, "one of the most serious questions that is posed, and posed here, between the university and the politico-economic outside of its public space" (p. 234). This questionable space is, for Derrida, "the marketplace in publishing and the role it plays in archivisation, evaluation, legitimation of academic research," and it lies for him, in this case at least, entirely within closed brackets (pp. 234-5).

Here, it will be otherwise. The main and open body of this chapter is concerned with the rude mechanics and marketplace of journal publishing, as a prominent channel of production in the scholarly mills of academic work. It is about current efforts "to find the best access to a new public space," as Derrida puts it just prior to his parenthetically setting this question aside, as that public space is "transformed by new techniques of communication, information, and archivisation and knowledge production" (p. 234). This chapter supplements Derrida's aside. It appends a means of finding at least a better, if not the best, form of access to a new public space, in the name of a Humanities unconditional in its resistance and persistence. It is concerned with improving one aspect in the material conditions of access to the work of the university, for those conditions determine the relation that Derrida asks us to consider, between university and politico-economic world. ${ }^{1}$ That aspect is access to scholarly journals. For his part, Derrida has

\footnotetext{
${ }^{1}$ Marx: "My inquiry led me to the conclusion that neither legal relations nor political forms could be comprehended whether by themselves or on the basis of a so-called general development of the human mind, but that on the
} 
worked on the material conditions of teaching in the Humanities, most notably through his contribution to the founding of GREPH (Groupe de recherches sur l'enseignement philosophique) in 1975 which has sought to further the teaching of philosophy (Derrida, 2000a). For my part, I have been among those who have been working for the last few years on developing an alternative model for journal publishing, as the journal system persists within a particular state of economic crisis that is, in effect, reducing access to knowledge for a growing number of faculty and students, especially those who work outside of the privileged sphere of well-endowed research libraries (Willinsky, in press).

Now, I realize that it may seem utterly perverse to speak, at this time, of a declining access to research and scholarship. Isn't this rather a time of instant access to too much information, from home and office, if not from airport lounge and hotel room? Yet it seems fair to claim that access to scholarship and research is declining as long as university libraries are forced to cancel journal subscriptions, even as increasing journal prices also erode the library's book acquisition budgets. Meanwhile, the number of journals increases. If the best research libraries have been forced to cut just over five percent of their journal titles, less fortunate libraries, especially those in developing countries, have decimated their already minimal serial collections (with some reversal of this through special free e-journal programs), and virtually eliminated book purchases. ${ }^{2}$ While university populations continue to grow on a global scale, journals are pricing themselves into an ever-narrower market of well-endowed research libraries, exchanging the reach of a wider circulation (of knowledge) for stable profitability.

In searching for an explanation of this economic condition, what stands out is the increasing degree of commercialization within scholarly publishing. It began in earnest after the Second World War. An upsurge in state support for research in the West in the midst of the Cold War led to increased supply and demand for published studies, and when the scholarly societies proved slow to respond, the commercial publishers stepped in to create new journal titles. The growth of this corporate involvement, especially in science, technology and medicine, has led to

contrary they originate in the material conditions of life, the totality of which Hegel, following the example of English and French thinkers of the eighteenth century, embraces within the term "civil society"' (1859).

${ }^{2}$ On the serial crisis, see the Association of Research Libraries website (http://www.arl.org) which demonstrates how the best libraries in North America cut 6 percent, on average, of their journal subscriptions between 1989 and 2000, and see Willinsky (in press) for a summary of far more drastic cuts among the minimal libraries of developing countries. On the monograph crisis and the related university press crisis, see Regier (2003). 
the same sort of corporate concentration that has taken place in rest of the media. ${ }^{3}$ In scholarly publishing, the result has been often exorbitant price increases for scientific journals which affects, in turn, access to journals in all disciplinary areas.

With print journals, a publisher's services are something of a necessity. That is not as obviously the case with this new digital medium of e-journals, and this dependence on the publisher has been called into question. Unlike the scholarly book, which has not found much of a home online, the journal has been drawn to the computer screen like a moth to a candle flame. ${ }^{4}$ The great journal migration to this online medium, however, altered the crisis state of this knowledge economy, as most journals persist in charging much the same subscription fees, if not more, for print-plus-online access. Still, more than a few journals are using these new technologies to reduce their costs sufficiently so that they are able to provide different forms of open access to their contents.

Well-known titles, such British Medical Journal and the New England Journal of Medicine, run by professional associations, continue to sell print subscriptions, while offering readers open access to their contents (if six months after initial publication, in the case of NEJM). BioMed Central represents the corporate model of open access, supporting 90 free to read journals in the life sciences by charging authors a fee for accepted articles. Then there are the independent open access journals, such as Postcolonial Text, which is a newly launched ejournal that utilizes Open Journal Systems, an online journal management and publishing package, an open source piece of software which is distributed for free, that I have been involved in developing. ${ }^{5}$ This open source (free) system allows it to operate on a zero budget (with volunteer copyediting and proofreading), as well as to have its principal editors located in Cameroon, India, South Africa, Sri Lanka, and the West Indies, as well as Canada. And yet it is

\footnotetext{
${ }^{3}$ As a result of mergers over the last few years, Elsevier, Springer, and Taylor and Francis control 60 percent of the journals in the leading citation index, ISI Web of Science (Merger Mania, 2003).

${ }^{4}$ A recent survey conducted by the Association of Learned and Professional Society Publishers reports that 72 percent of journals in the Humanities and Social Sciences, compared to 83 percent in the sciences, now have online editions (Cox \& Cox, 2003, p. 5).

${ }^{5}$ Open Journal Systems, developed through the Public Knowledge Project (http://pkp.ubc.ca), automates many of the management and clerical tasks of journal publishing, improving record-keeping while reducing management time, as well as eliminating photocopying, postage, and stationery costs, not to mention printing, distribution and subscription-management expenses.
} 
fair to say that the open access model has had the same impact on the journals in this field as it has in the sciences or social sciences. ${ }^{6}$

On one level this is perfectly understandable, given that those working in the Humanities are not so technologically inclined as those in the sciences, nor have their journals suffered the same drastic escalation of subscription prices, well into the thousands of dollars, nor do they place the same critical emphasis on journal publication as they do in the sciences. Yet journals in the Humanities do play a vital role in the intellectual life of this area, whether in giving ideas a trial run, prior to book-length treatments, in sustaining debate and exchange, and in creating a critical context for the analysis of major developments. Where the Humanities have gone some distance in increasing access to scholarly resources has been through projects such as the Rossetti Archive at the University of Virginia (with the complete writings and pictures of Dante Gabriel Rossetti), the still-in-progress Stanford Encyclopedia of Philosophy, or Project

Gutenberg (which offers many complete works of literature for which the copyright has expired and a smattering of the major philosophical texts, from Plato's Republic to Dewey's Democracy and Education).

Yet greater access to journals in the Humanities would seem both a critical and practical step toward the unconditional university imagined by Derrida. Converting journals to some form of open access would give, by far, more people a chance to experience what is current and critical, as well as tentative and open in the work of the Humanities. And access to research and scholarship has begun to be, at least among a certain class of readers, a real issue, judging by a recent New York Times editorial in praise of "Open Access to Scientific Research," in which it complained that scholarly publishing today "looks less like dissemination than restriction, especially if it is measured against the potential access offered by the Internet" (2003, p. A27). Not surprisingly, the Times sees the issue largely in terms of increasing public access to medical research: "Most of us, admittedly, will not have much use for free access to new discoveries in, say, particle physics. But it is a different matter when it comes to medical research. Popular nostrums abound on the Web, but it can be very hard, if not impossible, to find the results of properly vetted, taxpayer-financed science - and in some cases it can be hard for your doctor to

\footnotetext{
${ }^{6}$ The Directory of Open Access Journals at the University of Lund lists seven journals in philosophy at this point, including Animus and the African Journal of Philosophy and nine in language and literature, including Agora and Romanticism on the Net. The variations include Postmodern Culture which offers open access only to its current issue, while College English offers access only to back issues. The Stanford Encyclopedia of Philosophy, while obviously not a journal, deserves noting as a wonderful open access resource.
} 
find them, too." The very right of access to any of this knowledge, whether on particle physics, cancer treatments, or human rights, seems to me more fundamental than whether "most of us," as the Times puts it, will "have much use" for it. This is why the Humanities need to be part of this struggle over the political economy of knowledge.

Now, I recognize that to pin any form of hope on a shift from print to electronic publishing may seem to reinforce the very real digital divide that separates those who have access to the Internet and those who do not, a divide which will continue to condition access to knowledge as surely and for as long as any of the other divides by which we live. But in the case of access to scholarship, we need to first recognize that print journals have been contributing to an economic divide that has continued to grow over the last two decades, to the point where to walk into a university library in Nairobi is to find that there were no longer any print subscriptions or to visit the Kenyan Medical Research Institute is to find it hanging onto its final five subscriptions. I do not think it too much of an exaggeration to say that, in this particular knowledge economy of scholarly publishing, print reached its limits decades ago in the circulation of knowledge on a global scale, and is now contributing to an increasing gap between who has access to this knowledge, and thus the right to participate in its production.

On other hand, the very machinery of contemporary scholarly production and transmission - the computer and the Internet - is slowly being distributed among universities around the world. The conditions of access to the technology can amount to no more than five computers in an African university library or no student access, except through a librarian (Muthayan and Muinde, 2003). Yet even then, these inadequate technologies, by our standards, have already begun to make it possible for faculty and students in disadvantaged institutions to access a much greater part of this academic world of knowledge than they had been able to through print, and this increase has, in turn, improved their opportunities for contributing to this knowledge (Willinsky, in press). The capacity of these new technologies to reduce dissemination costs have made it possible for the World Health Organization and International Network for the Availability of Scientific Publications to convince donors and sponsors (including commercial publishers) to provide faculty and students in developing countries with open access to electronic editions of thousands of titles. It costs the journal publishers little enough to grant this open access to their journals in developing countries, but it has already altered, but by no means alleviated, the devastating conditions of access that are the result of our current journal economy. 
If the university is to be without condition any time soon, and if we mean by university a global pursuit of higher learning, and if the university is to possess, in Derrida's words, "an unconditional freedom to question and assert, or even the right to say publicly all that is required by research, knowledge, and thought concerning the truth" (p. 233), then access to that questioning and saying, and access to the scholarly apparatus that determines what is asserted publicly, is a critical first step. After all, does the "right to say everything" mean anything at all, if the "right to say it publicly, to publish it" does not allow for some experience of how others are saying and publishing it through their scholarly work? This is only to say that scholarly work, especially as it is supported by public or publicly spirited institutions, should be made as available as economically possible, and thus this need to explore and test the new economics of electronic journal publishing to see what it could make of a greater access to this particular knowledge work that goes on in universities.

To speak of improving the material conditions of access to journals is to speak of a human right to know what is known. This right is not just about being able to read of others exercising an unconditional freedom to question and assert, but to see that it is within one's reach, as a member of that global community, to participate in that freedom, to see the possibilities of exchange and circulation to this knowing, to acquire the means of contributing to this knowledge. Nor is open access only about the circulation of this knowledge within a global university community. To move journals into an open access model means that they are also available in public libraries, community centers, colleges, and high schools, where with print journals there has rarely even been a question of access to this knowledge.

The journal is also a natural point of interest for increasing open access because of how it emerges out of the special, if not-quite-unconditional, contribution made by authors, editors and reviewers to journals, which is not typically the case with scholarly books. The freely given quality of the journal has its own way of rooting this knowledge as a public good. It provides the basis for faculty members reasserting their property rights over their work, rights which they otherwise sign away to journal publishers, who perversely insist that the journal could not be published unless they own the work outright (as opposed to being granted a limited right of first publication). The journal is the perfect site for a practical reassertion of scholarship's place within the public domain. 
A good number of scholars already use the journal to exercise, as Derrida advocates, the right to speak and to resist unconditionally "everything that concerns the question and the history of truth, in its relation to the question of man, of what is proper to man, of human rights, of crimes against humanity and so forth... above all in the Humanities" (p. 234). Yet it makes something of a mockery of this independence to have the resulting knowledge otherwise safely placed out of harm's way, hidden behind passwords and research library doors. How do those who are interested in seeing the university resist the powers of state or economy imagine this can happen when they are so little interested in making the basis of that resistance - the knowledge and substance that makes resistance necessary, sound, comprehensible, and reasonable available to anyone who lives and works outside of the relatively small circle of well-endowed universities? So along comes this moment, when it might just be possible to speak truth to power on a larger scale, to marshal evidence and argument on behalf of those who cannot otherwise muster such resources in a more open fashion. If the university is to profess an "unlimited commitment to the truth," as Derrida puts it, it must at some point be concerned with the right of access to that truth (p. 234).

In this sense, the incipient open access movement in journal publishing has something to offer to the "right to philosophy" that Derrida addresses in his work with the philosophy teaching group, GREPH, with its goal of organizing "a body of research in the connections that exist between philosophy and its teachings" (Derrida 2002b, p. 97). He speaks of this right to philosophy in three important senses. It is for him a fundamental right to philosophy; it is about going right to philosophy; and it is a question of who has the right to philosophy (p. 3). And yet for Derrida, it is a right that is achieved in the very spirit of philosophy: "Philosophy is the most easily shared thing in the world. No one can forbid access to it. The moment one has the desire or will for it, one has the right to it. The right is inscribed itself" (p. 23).

As for how to go about this right to philosophy, and to the Humanities more generally, Derrida calls for a "necessary 'delocalization' to the teaching body" (p. 113). I take this delocalization to be about opening access to the very court of this philosophy, taking the back and forth quality of philosophy out of doors, beyond the cloistered quad, and into the piazza, much as the Royal Society of London, which formed in the seventeenth century, grew out of coffee-house discussions, giving rise, in the process, to a pamphlet publication of miscellaneous experiments and natural history findings for a wider public, with the Philosophical Transactions 
first published in 1665 by its secretary Henry Oldenburg now regarded as the first scientific journal in English. Only this time, the public sphere is delocalized in a global, virtual sense.

Derrida recognizes this universal right to philosophy is not without some risk. It does make philosophy "more accessible to ideological misappropriations or to its dissolution in nonphilosophical disciplines," and he stands up for what is unique about philosophy's contribution, defending its need to "train" students in "critical vigilance" against what philosophy might otherwise become among the human sciences (2002a, 112). The available means for recognizing that right, for philosophers to fulfill the one human right that is entirely up to them to acknowledge or withhold, is through training and teaching. So while Derrida speaks of philosophy as that which is most easily shared, as if it were simply part of the language freely spoken, he is just as quick to acknowledge that it depends, in fact, on structured and deliberate efforts to support this undeniable access, namely through training, in his case:

To have access effectively, in effect, to these discursive procedures and thus to have the right to the philosophical such as it is spoken, for philosophical democracy, democracy in philosophy, to be possible (and there is no democracy in general without that, and democracy, the democracy that remains still to come, is also a philosophical concept), one must be trained in the these procedures. (2002a, p. 29, original emphasis).

GREPH was dedicated to increasing access to the teaching of philosophy, not just at the university level but in the schools and elsewhere, and this clearly distinguishes it from my project, which is all about opening the pages of philosophy and other journals to those who might find their way to them. Derrida was, some 30 years ago, working with others to uphold the "the right to teaching," which bears a connection to the movement for open admissions, perhaps most notably with the founding of Britain's Open University in 1969. (2002a, p. 36). This "right of access (to whatever, teaching, philosophy, and so forth) assumes the access to right, which assumes the capacity to read and interpret, in short, instruction" (ibid.).

I do not want to undermine the value of being able to study philosophy with a good teacher, in my efforts to open access to the journals. Much of what scholarly journals contain is given to technical minutiae and hair-splitting debate that will remain inaccessible for the common reader, even with the very best teaching. But not all of it. And access to teaching and to 
the literature can go hand in hand in extending this right to philosophy. Derrida holds to the idea that this ability to reach a wider audience is itself a test of philosophy, and quotes, to that effect, Kant's insistence "that every philosophical teaching be capable of being made popular (that is, of being made sufficiently clear to the sense to be communicated to everyone), if the teacher is not to be suspected of being muddled in his own concepts" (cited by Derrida, 2002a, pp. 44-45). Kant felt that going public and "being made popular" is part of what philosophy should do, as a philosophy is often referred to as a teaching. Kant also set out implicit limits to that teaching in answering the question of what is Enlightenment in the pages of the newspaper Berlinische Monatsschrfit in 1784. His response to the question was to invoke Horace and declare that "the motto of enlightenment is therefore: Sapere aude! Have the courage to use your own understanding!" (1970, p. 54, original emphasis). In this op-ed piece, he called for a "freedom to make public use of one's reason in all matters" and "without outside guidance" (pp. 55, 58, original emphasis). This teaching is aimed at moving people out from under the tutelage of others. It can be supported by increasing people's access to resources that would support this public reasoning and freedom.

Certainly, these new machines are increasing access to university instruction. The open universities have been among the first to use new technologies to improve distance education. MIT has an Open Knowledge Initiative that is setting standards for learning technologies, and its OpenCourseWare is designed to "provide free, searchable, coherent access to MIT's course materials for educators in the non-profit sector, students, and individual learners around the world," as the website puts it, and it does so "to advance knowledge and education to best serve the nation and the world," with the support of Hewlett Packard and the Andrew Mellon Foundation. This does not mean that you can take the courses for free, at least not for credit, although some of the texts being studied are through open access sites. ${ }^{7}$

MIT's efforts to open the material basis of learning, to support teachers and learners through access to its course materials is consonant with the drive for open access to journals. Each journal that moves to open access offers teachers and students resources that could add to the learning experiences of both, especially in universities where such resources are otherwise

\footnotetext{
${ }^{7}$ For example, Sally Haslanger at MIT has placed her first-year Problems of Philosophy course in OpenCourseWare, and it includes her lecture notes for 2001, beginning with the Ontology Argument, and the list of readings, from Dostoevsky to Nietzsche, as well as a practice exam that asks whether Bill Gates, should he give all of his money to famine relief in order to achieve a Nobel Prize, is still praiseworthy and morally permissible: "Explain and justify your answer in light of the moral theories we've considered."
} 
scarce. It could also make all the difference for the high school teacher or student seeking to take a step beyond the standard curriculum.

Still, increasing access to scholarly journals is about a right to philosophy and the Humanities which goes beyond supporting instruction. This philosophical training, to use Derrida's word, with its reading regimen and exercises, is bound within pedagogy's inevitable power relations, as he also notes. ${ }^{8}$ The broader sense of philosophy, as inherently a form of teaching, is something that persists outside of the classroom, as does the right to this philosophy, whether on an ongoing or occasional basis, whether for the policy analyst trying to frame a common social issue in a new way, as well as for the common reader, who, having enjoyed the work of Stephen Hawking, might happen upon Hélène Mialet's article in Critical Inquiry on the mind-body dilemmas of scientific "genius" that arise in her interview of him (2003), while a fan of David Cronenberg films might find, in the same issue of Critical Inquiry, Teresa de Lauretis' analysis of his 1999 film, eXistenZ, which she treats as "a reflection of the new technologies of postmodernity - information, communication, and biotechnologies and the new interactive media" (2003, p. 547).

This right to philosophy should not require that citizens be enrolled, registered, assigned, and taught, in order to qualify for this right to knowledge. If the Humanities is going to increase its presence in that relation between university and the politico-economic world, if it is going to play a more integral role in the democracy to come, as Derrida emphasizes (2002b, p. 13), then where this knowledge stands, as public and published good, should be opened, no less than the classroom door.

The specter of learning in the Humanities at issue here, then, is more about what is selftaught. This autodidactism accounts for so much of what we know and has always been the working person's tutor, the lifelong learner's best instructor. For teachers, the best moments of teaching often arise from just being there, in the presence of a student who is figuring it out for herself. And much learning takes place without a teacher in sight. Such is my case for scholars to open the fields of their own best learning to this larger body of students and readers by taking advantage of these new publishing technologies to reconstruct the journal publishing economy. It could expand the potential universe of learning, following on the tradition of the public library

\footnotetext{
${ }^{8}$ Derrida would not have "us think or dream of teaching without power, free from teaching's own power effects or liberated from all power outside of or higher than itself" (2002, p. 79).
} 
movement and other efforts at popular self-education. It could assist Derrida in pursuing the lofty ideal of "ensuring each citizen the chance of encountering one of three things that are called philosophy at least once in his or her life," then we need to open more that access to teaching (2002a, p. 39).

Yet in introducing this public right to philosophy into the argument for open access, I am not asking scholars to redirect their efforts toward catering to this expanded audience. Certainly, money is being made in writing quickie guides, from Plato for Beginners to Kant in 90 Minutes, judging by the number of these series, covering the same hoary figures, found in bookstores these days. The apparent success of these series only adds to the argument that open access to the journal literature, where the same ideas are fully alive and critically engaged, may attract a greater audience than anticipated, even if the size of that audience matters little if this is indeed a right to know. Yet the value of this literature remains in its scholarly achievements, and it owes that wider public and professional audience (e.g., policymakers, teachers, etc.) no more than the right to know what is known, especially when that right is realizable on a much greater scale although by no means on a universal basis - through new journal publishing technologies.

Now, it may happen that opening scholarly literature to this larger audience will gradually alter its own tone and tenor, as writers find their work unconsciously affected over time by the light of day shining in on it. The writing may be altered as well, as it takes shape in the knowledge that it must now work its sense and sensibility for a larger world than before. Open access is not, however, about abandoning the scholarly project in any way. Rather, it is about reasserting a basic principle about the nature of knowledge. I am referring to the belief that the circulation of knowledge is vital to its very claims, as knowledge, and that a continuing decline in that circulation does not bode well for the future of the university or what it would make of knowledge, especially as that academic community continues to expand on a worldwide basis.

I am siding here with Helen Longino, who in her efforts to move beyond the "science wars," establishes in The Fate of Knowledge how "the social is not a corrupting but a validating element in knowledge" (p. 122). She treats the social restrictions or material conditions that typically hamper a qualified candidate's ability to participate in research and scholarship, whether through economic disparities or forms of discrimination, as simply a "cognitive failure" 
that diminishes the quality of knowledge through which we understand the world (p. 132). ${ }^{9}$ It represents a failure, on the part of the academic community, to subject its ideas to the largest possible hearing, and that failure is directly attributable to a knowledge economy that may be unduly restricting access and participation in the circulation of that knowledge. Again, it may seem bizarre to suggest that the current state of access to journals amounts to a cognitive failure among the "epistemic community," to use another of Longino's terms (p. 132). And while radical gains have been made in some areas in the last few years, notably in the amount of medical research available to universities in impoverished countries through the efforts of WHO, my case is that a great deal more can be done by this community to improve access in this particular area of the journal literature.

Without addressing the material conditions of journal publishing, Longino adds to this open access argument by stressing how this community "must also take active steps to ensure that the alternative points of view are developed enough to be a source of criticism and new perspectives" (p. 132). This requires, to her mind, "publicly recognized forums for the criticism of evidence, of methods, and of assumptions and reasoning," which is what the journal literature represents already, one might argue, except that its public inaccessibility certainly hampers its public recognition as such a forum (p. 129). Without trying to tie Longino into my argument for open access to journals, this model does address her concerns over "limitation of space" as well as "the privatization of information and ideas", which "contribute to the marginalization of critical discourse" (ibid.) It also poses a relatively easy way to address the need, she identifies, to "help citizens acquire a tolerance for the provisionality, partiality, and plurality of knowledge" (2003, p. 213). For nowhere is this aspect of knowledge more readily apparent than in the give and take of journals.

None of this, I should state, requires that scholars alter what they make of their work in the Humanities. This is not a call for greater "relevance," or a veiled threat to academic freedom. Let scholars pursue their right of resistance or not. I only ask that some notice be taken of the material conditions of this knowledge's circulation, as it bears on the quality of that knowledge, both in an epistemological and democratic sense, and I only ask this in light of the new alternatives opened up by the wholesale move of journals to online publishing environments. But

\footnotetext{
${ }^{9}$ Longino: "The exclusion of women and members of certain racial minorities from scientific education and the scientific professions constitutes not only a social injustice but a cognitive failing. Similarly, the automatic devaluation in Europe and North America of science from elsewhere constitutes a cognitive failing" (2002, p. 132).
} 
not only can those working in the Humanities continue to pursue their scholarly interests whether or not it is concerned with unconditional forms of academic resistance - they can see their star rise by publishing their work in journals using some form of open access policy. I mean this not only in a moral sense, but in the crassest career and financial sense, as open access dramatically increases readership and levels of citation for authors whose work is freely available. $^{10}$

Having made this case for supporting a wider audience among scholars, students and the public, let me also make it clear that putting journals online is not simply a matter of pasting pages on a screen. The challenge is to design a new publishing environment that stays true to the scholarly article, while furthering its scholarly and public qualities. Without going into the technical details of online publishing here (yes, one aside leads to another, let me say parenthetically in turn), let me offer the example of the Public Knowledge Project, with which I work. We are developing publishing systems designed to provide readers with richer context and background for approaching any give article. These systems provide the reader with a ready means to check their reading of a piece, with a click or two, against what is being said in related work, to gather background on the author, as well as view other works, and to trace the ideas presented through other forms, whether among media databases, government policies, or historical archives. ${ }^{11}$

We have now to test whether providing readers with this greater context extends their reach within this literature (or just confuses, distracts, and annoys them). We also want to know if making it easier to situate an article within this broader context could add to the scholarly quality of the work itself, as it supports both the writing and review process. While we do not have the answers to these questions yet, it is hoped that if we can arrive at improved designs for scholarly publishing it will add to the argument in favor of increasing access to this literature.

\footnotetext{
${ }^{10}$ The empirical basis is admittedly thin for this claim, but Steven Lawrence compared citations levels for comparable sets of print and open access computer science papers, and found the open access papers were cited four times as often (2001). Gene Glass reports on how the two leading articles in the open access Education Policy Analysis Archives journal which he edits have received over 50,000 hits with the frequency of visits continuing to grow, with the daily visits from "unique visits" to the journal in the area of 2,500 (2003).

${ }^{11}$ For example, with the publishing system we have developed, a Research Support Tool offers readers links to open access resources related to the article which they are considering, on the assumption that they do not have access to a research library or may not know how to use one effectively. The reader's search through these resources is further directed by the key concepts the author has identified for their work, thereby providing a much richer context supporting the reader's understanding and interpretation of the work. See the Research Support Tool demonstration on the Public Knowledge Project (http://pkp/ubc.ca).
} 
Our very pursuit of these questions bears its own relation to the Humanities as a field that would seek to understand how texts are read and interpreted, and regards close reading its default methodology.

As this new publishing environment we are experimenting with integrates scholarship with other public domains of discourse, it has everything to do with Derrida's political agenda for the unconditional university and the right to philosophy, and for what he frames as, in a related work on this theme, the debt and duty associated with the right to philosophy (2002b, pp. 16-17). ${ }^{12}$ For if the relation between the university and the world outside of it is about the democracy to come, as Derrida would have it, then the university has some responsibility for knowledge's vital role in democracies. The Internet has raised our expectations of the information that governments and other agencies make available; it has accelerated the mobilization of political alliances and informed political action, and it has led to experiments in public deliberation and policy consultation. ${ }^{13}$ It has created a knowledge commons, one to which scholarship's contribution stands to be greatly increased in a systematic fashion. As access to knowledge is both a democratic right and a necessity, it does not seem unfair to think that Humanities scholars should be among those who should be instrumental in establishing the public right of access to this public good otherwise known as scholarship. On the other hand, to continue to demonstrate relative indifference toward the public accessibility of our own work makes it that much more difficult, surely, to call others on their philosophical shortcomings and democratic failings. ${ }^{14}$

Improving access to this knowledge has everything to do, as well, with the democratic quality of life among communities operating across national boundaries, such as the universities as forming a global community, and how the democratic right of representation and participation in that republic of scholarly letters might be advanced by wider rather than restricted access to

\footnotetext{
${ }^{12}$ Peter Pericles Trifonas goes some distance to connecting the democracy to come to public education in his commentary on Derrida, when Trifonas analyzes how "the right to philosophy' is also a question of democracy and of the right to all to participate in the curricular orientation of a public education" $(2002$, p. 89).

${ }^{13}$ For a discussion of the limits of the U.S. government's handling of the post-Bhopal Right-to-Know legislation around environmental issues, within the context of "empowerment as access," see Wyatt Galusky (2003). On the use of the Internet for the mobilization of resistance through the Zapatista Movement, see Maria Garrido and Alexander Halavais (2003).

${ }^{14}$ While the right to this knowledge is obviously not based on a person's qualifications, the question of whether deliberative democracy (which I see open access to scholarship supporting) favors those who already possess the capacity to deliberate (and read research), is addressed by Cohen and Rogers, who point to examples of wide participation in deliberation, based on interest and opportunity, as well as to the use of training programs on deliberative planning processes (2002, pp. 244-246).
} 
the journal literature is one small but vital part of that in the global exchange and circulation of knowledge that constitutes the democratic work of the university. That quality of this democratic right depends on many factors, from being so underpaid and overworked by your institution that conducting research is not possible, to having a reliable source of electricity. But the democratic quality of this academic community surely relies, as well, on the very thing that each of us (as authors, editors and members of scholarly associations) in the university community helps to determine, and that is the material conditions of access associated with the circulation and exchange of scholarship and research.

As I have already suggested, this is not about scholarship in the Humanities having to prove its relevance to democratic life. The cases that have been made for the contributions of this work can continue to be made. Rather, the very effort to make our scholarship more open speaks to reasserting knowledge's place within the public sphere so vital to democracy. To position a greater portion of this work as a freely available public good establishes an alternative to the competitive and corporate scope of global knowledge economies. And it does so, of course, on a global rather than national basis, although not without raising questions of linguistic imperialism that are hardly new to research and scholarship. After all, if we are to deconstruct our own history, asking critical questions of "the history even of the notion of critique" (p. 235), then we are bound to confront the scope of isolation and solipsism that besets the closed circle of scholarly work, as if publishing in the best journals, with the best publishers, were a critical, deconstructive end in itself.

Our independence as scholars has rested for too long on the inaccessibility of this work, not just in what is at times the necessarily convoluted nature of language, but as a result of the relative obscurity in which it circulates. Derrida's notion, then, of the "weakness and vulnerability of the university" is as much, for me, about its own failure to recognize its responsibilities to a larger academic community that has developed on a global basis (p. 236). How are we to protect the independence and resistance of the university, if we have turned the knowledge at issue into its own source of inequality through indifference to the material conditions of access, in a vain pursuit of greater publishing glory?

The critique that Derrida calls for - "in which nothing is beyond question" (p. 235) must begin, much like charity, at home. We need to see how readily we allow our scholarship to become subject to corporate interests in a knowledge economy of ruthless exclusion, mergers 
and acquisitions, surveillance and enforcement. ${ }^{15}$ Universities may currently be at risk, Derrida warns, of "becoming a branch office of conglomerates and corporations," but the knowledge we produce is already, in too many cases, a corporate asset, whether of Blackwells, Taylor and Francis, or Cambridge University Press, as a condition of publication (p. 237).

If we are indeed to make something of the Humanities' special powers to resist, through its embrace of theory, its unrelenting questioning, then scholars working in this area need to put their words where, as it were, their mouths are. That is, they need to find ways of deconstructing a publishing system that delimits access in favor of one that creates a public and global organ, open to scholarly participation and common readers that provides its own incentive to the spread of the Internet. The digital divide that we need to be concerned with is the divide constructed between those with access to this knowledge and those without. For it is that divide alone that is immediately and directly in our hands to control and overcome. To put it far too simply, what we give for free to publishers, we need to make free to readers and colleagues, where it can do us the most good, in an intellectual, altruistic, and personal sense. The copyright over scholarship is ours, in the first instance, under the special academic exception we are afforded as part of scholarship's public trust (McSherry, 2001). It would otherwise seem that we are squandering that trust at this point, out of an indifference to such economics of access, and in pursuit of the career rewards of publishing in the top journals.

How is open access to the journal literature in the Humanities to be achieved in this immediate and direct way? There are a number of routes. Certainly, the easiest is to simply post a copy of their work on the web, in addition to publishing it elsewhere, as I have done with this chapter. This can be done on one's own home page, but the best way to do it is to place the article in what is called an "eprint archive," where is it indexed and thus all the more openly available (Harnad, 2003). These archives are being set up by universities and by subject area, with the software for them freely available, and with many journals having explicit policies allowing such a free posting. ${ }^{16}$

\footnotetext{
${ }^{15}$ A recent agreement with Elsevier Science in India forces librarians to forbid those who "walk in" to the library (as opposed to being members of the library) - never mind that they traveled for two days to do their research at that library - to print out or otherwise "save" a copy of the journal article they are reading online in the subscribing library.

${ }^{16}$ See Project Romeo (Rights Metadata for Open Archiving) for journal policies on eprint archiving (http://www.lboro.ac.uk/departments/ls/disresearch/romeo/). The arXiv.org Eprint Service, to which high energy physicists have been contributing papers for the past decade is the best example in this field thanks to the pioneering work of Paul Ginsparg (2001). The paper is placed there before it is published (in what was known as a "preprint"),
} 
A second route to open access is to involve editors, editorial boards and possibly scholarly associations in converting existing journals to some form of open access. Open access for existing journals can take the form of immediate and complete access to the online edition of the journal (with perhaps a print subscription system retained in place), or it can amount to delayed open access which is offered some months after initial publication to subscribers, or it can be made geographically exclusive, with open access made available to those who register for this service from developing countries.

A third route to open access is to start a new journal that is designed from the outset to make its contents free to read, which is what we have done with Postcolonial Text. Such journals can take advantage of open source management software to reduce their costs, involve a wider range of editors as the journal's office is virtually located everywhere, and deploy innovative tools for providing a richer context for reading. Improving the material conditions of access to the contents of these journals augments the circulation of knowledge.

Within that part of the Humanities devoted to a resistance that exercises the right to say everything publicly, there has yet to emerge a systematic effort to open this scholarship in a regular way to the public spaces of the Internet. My supplement to Derrida's aside, then, would prompt Humanities scholars, who are otherwise taken with principles of unconditional resistance, to look up from their screens and books long enough to consider the rude mechanics of where and how their work is delivered to the world. It seems entirely consistent with their own interests in the nature and history of knowledge to attend to new and experimental efforts in publishing, in their democratic and global claims to be representing what is properly the right of humankind. To increase democratic access to knowledge in this way certainly has its risks, its trade-offs, its loss of privilege. It will mean more of the same in the journal literature, a further crowding of already crowded fields. It could well lead to greater specialization, and the reading of more about less. And then there is the inevitable loss of the fine paper, the smell of glue and ink, that have long marked the journals that arrive in the mail.

It is not that there will ever be unconditional access to the work of scholarship, any more than we will ever come to work in unconditional institutions, except in that nether world of what

and it is there after it is published in one of the physics journals. Unfortunately, arXiv.org has little affected the need for libraries to subscribe to physics journals (which conduct the reviews), with average subscription prices well over a thousand dollars annually for this discipline, even as most faculty access the literature through the free arXiv.org Eprint Service. 
could take place tomorrow. Yet at this point, today, we may have an historic opportunity to change the material conditions of access to this knowledge that we work so hard to produce. It's true that the changes called for here are opportunely focused on that narrow band of our work that makes up the journal literature. Yet each journal that takes this step of opening itself to this larger public space serves as a demonstration of the place that such knowledge can occupy within the democracy that is here now, as well as within the one to come, in part as a result of such efforts.

\section{References}

Cohen, Joshua and Joel Rogers. (2003). Power and reason. In Eds. Archon Funga and Erik Olin Wright, Deepening democracy: Institutional innovations in empowered participatory governance (pp. 237-255)

Cox, John and Laura Cox. (2003). Scholarly Publishing Practice: The ALPSP report on academic journal publishers' policies and practices in online publishing. Worthing, UK: Association of Learned and Professional Society Publishers.

Derrida, Jacques. The future of the profession or the unconditional university (Thanks to the "Humanities" what could take place tomorrow).

Derrida, Jacques. (2002a). Who's afraid of philosophy: Right to philosophy I (Trans. Jan Plug). Stanford, CA: Stanford University Press.

Derrida, Jacques (2002b). Ethics, institutions and the right to philosophy (Ed. and Trans. Peter Pericles Trifonas). Lanham, MA: Rowman and Littlefield.

Galusky, W (2003). Identifying with information: Citizen empowerment, the Internet, and the Environmental Anti-Toxins Movement. In Eds. Martha McCaughey and Michael D. Ayers, Cyberactivism: Online activism in theory and practice (pp. 185-205). New York: Routledge.

Garrido, M. \& Halavais, A. (2003). Mapping networks of support for the Zapatista movement: Applying social-networks analysis to study contemporary social movements. In Eds. Martha McCaughey and Michael D. Ayers, Cyberactivism: Online activism in theory and practice (pp. 165-184). New York: Routledge. 
Ginsparg, Paul. (2001). Creating a global knowledge network. A paper presented at Second Joint ICSU Press-UNESCO Expert Conference on Electronic Publishing in Science, Paris. http://arxiv.org/blurb/pg01unesco.html.

Glass, Gene (2003). Education Policy Analysis Archives activity. Paper given at American Educational Research Association Conference, Chicago.

Harnad, S. (2003) Electronic preprints and postprints. Encyclopedia of Library and Information Science Marcel Dekker, Inc. http://www.ecs.soton.ac.uk/ harnad/Temp/eprints.htm.

Lawrence, S. (2001). Online or invisible? Nature, 411(6837), 521. Retrieved April 30, 2002, from http://www.neci.nec.com/ lawrence/papers/online-nature01/

Longino, Helen. (2002). The fate of knowledge. Princeton, NJ: University of Princeton Press. Marx, Karl. (1859). Preface to A Contribution to the Critique of Political Economy (Trans. W. Ryazanskaya). Moscow, Progress Publishers, Moscow. http://www.marxists.org/archive/marx/works/1859/critique-pol-economy/

McSherry, Corynne (2001). Who owns academic work: Battling for control of intellectual property. Cambridge. MA: Harvard University Press.

Merger Mania (2003). Scholarly Communication Reports, 7(5), 2.

Regier, Willis S. (2003, June 13). 5 Problems and 9 solutions for university presses. Chronicle of Higher Education, B7-B9.

Trifonas, Peter Pericles (2002). What comes next? Or after difference: Meditations on the debt and duty to the right of philosophy. In Jacques Derrida, Ethics, institutions and the right to philosophy (Ed. and Trans. Peter Pericles Trifonas) (pp. 57-105). Lanham, MA: Rowman and Littlefield.

Willinsky, John (in press). Open access to research and scholarship. Cambridge, MA: MIT Press. 